\title{
REVIEW
}

\section{Travelers With Sickle Cell Disease}

\author{
Shaina M. Willen, MD, ${ }^{*}$ Courtney D. Thornburg, MD, ${ }^{\dagger}$ and Paul M. Lantos, MD, CTH ${ }^{\ddagger \S}$ \\ ${ }^{*}$ Department of Pediatrics, Duke University Medical Center, Durham, NC, USA; ${ }^{\dagger}$ Division of Pediatric Hematology and \\ Oncology, University of San Diego Medical Center, San Diego, CA, USA; ${ }^{\ddagger}$ Division of Pediatric Infectious Disease; ${ }^{\circledR}$ Division of \\ General Internal Medicine, Duke University Medical Center, Durham, NC, USA
}

DOI: $10.1111 /$ jtm. 12142

\begin{abstract}
Background. Sickle cell disease (SCD) is the most common genetic disease among persons with African ancestry. This article provides a background to SCD and reviews many important aspects of travel preparation in this population.

Methods. The medical literature was searched for studies on travel-associated preparedness and complications in individuals with SCD. Topics researched included malaria, bacterial infections, vaccinations, dehydration, altitude, air travel, and travel preparedness.

Results. There is very little published literature that specifically addresses the risks faced by travelers with SCD. Rates of medical complications during travel appear to be high. There is a body of literature that describes complications of SCD in indigenous populations, particularly within Africa. The generalizability of these data to a traveler is uncertain. Combining these sources of data and the broader medical literature, we address major travel-related questions that may face a provider preparing an individual with SCD for safe travel.

Conclusions. Travelers with SCD face considerable medical risks when traveling to developing tropical countries, including malaria, bacterial infections, hypovolemia, and sickle cell-associated vaso-occlusive crises. For individuals with SCD, frank counseling about the risks, vigilant preventative measures, and contingency planning for illness while abroad are necessary aspects of the pre-travel visit.
\end{abstract}

$\mathrm{S}_{\mathrm{i}}^{\mathrm{i}}$ ckle cell disease (SCD) is a group of inherited, autosomal recessive red blood cell disorders caused by hemoglobin S (HbS). This common severe disease is the most important of the inherited red blood cell disorders. HbS results from a single amino acid substitution in the beta chain of hemoglobin. Heterozygous individuals with the sickle cell trait (HbAS) are asymptomatic. In contrast, individuals with homozygous disease (HbSS) and other forms of SCD have varying degrees of hemolysis and vaso-occlusive disease, often colloquially referred to as "sickle crises." Chronic organ damage to the spleen, kidneys, brain, lungs, and bones contributes significantly to the morbidity experienced by children and adults with SCD. Individuals with SCD are also at risk for life-threatening complications, including sepsis, severe anemia, splenic sequestration, acute chest syndrome (ACS), and stroke.

Corresponding Author: Paul M. Lantos, MD, CTH, Divisions of Pediatric Infectious Disease and General Internal Medicine (DUMC), Durham 100800, NC 27710, USA. E-mail: paul.lantos@duke.edu
Despite improvements in care, individuals with SCD still suffer from substantial morbidity and mortality. Many patients with SCD have poor health-related quality of life, and are at high risk for mortality at a young age. ${ }^{1}$ SCD is the most common genetic disease among persons with African ancestry. It should thus be reasonably common among people traveling to Africa to visit family. In addition, the trans-Atlantic slave trade brought many African people to the Caribbean Islands and South America, particularly modern-day Brazil. The East African slave trade brought many African people to the Arabian Peninsula and South Asia. It should thus be recognized that not all individuals with SCD apparently have African ancestry; such patients may travel to visit family in many parts of the tropical and/or developing world.

\section{SCD and Travel}

There have been very few systematic studies or even case series of international travel in the SCD population, and yet fewer in the population with the thalassemias and other erythrocyte disorders. Still, the general theme 
emerges that compared with otherwise healthy travelers, the SCD population is at substantial risk for a medical complication while abroad (Table 1). While this body of literature is quite heterogeneous, one series of 148 travelers with SCD found that nearly 2 out of 3 developed an acute medical condition while abroad, and overall more than $10 \%$ required hospitalization overseas. ${ }^{2}$ This sobering finding should inspire frank discussions with SCD patients and their families about the potential risks of international travel, especially to developing countries and for long durations. These discussions may include discouraging high-risk travel altogether in some cases.

\section{Global Burden and Epidemiology}

Children born with SCD in the United States or in other high-income countries typically survive into adulthood, albeit with a variable degree of chronic illness. The median survival in the United States for males and females with SCD is now 42 and 48 years, respectively. ${ }^{3}$ This relatively good survival rate can be attributed to universal newborn screening and early detection, prophylactic penicillin, and high-quality, comprehensive medical care. ${ }^{4}$ By contrast, in Africa it is estimated that $50 \%$ to $80 \%$ of infants born with SCD die before the age of 5 years. ${ }^{5}$ In sub-Saharan Africa, the leading cause of mortality in SCD is infection, most commonly caused by Streptococcus pneumoniae and Salmonella. ${ }^{4}$

\section{Care of Patients With SCD}

One of the primary components of caring for an individual with SCD is health care maintenance, which usually requires a team of physicians, nurses, health educators, and medical social workers. By teaching patients and caregivers to recognize the early signs of specific illnesses and to understand the need for prompt evaluation of fever, many of the complications of sickle cell anemia may be reduced.

Management of SCD involves management of complications, and prevention of infection (see later) and vaso-occlusive complications. The only known preventive therapy for complications of SCD is hydroxyurea, a chemotherapeutic agent that induces fetal hemoglobin $(\mathrm{HbF})$ expression in patients with SCD. Hydroxyurea prevents pain crises, ACS, the need for transfusion, and hospitalizations in children and adults. Hydroxyurea is safe and efficacious in children as young as 9 months of age. ${ }^{6-9}$ Blood transfusions decrease anemia and can temporarily reduce the amount of sickling. Blood transfusion is generally reserved for life-threatening complications as well as secondary stroke prevention. Bone

Table 1 Summary of published case series and case reports of travelers with sickle cell disease and their medical complications

\begin{tabular}{|c|c|c|c|c|c|}
\hline References & Cases & Age & Destination & Duration & Complications \\
\hline $\begin{array}{l}\text { Morbidity among child travelers } \\
\text { with sickle cell disease visiting } \\
\text { tropical areas: an observational } \\
\text { study in a French tertiary care } \\
\text { center }^{16}\end{array}$ & 39 & $\begin{array}{l}4.3-11.7 \text { years } \\
\quad(\text { median } 7.8)\end{array}$ & $\begin{array}{l}\text { Mali, } n=14 \text {; Ivory Coast, } \\
\quad n=6 ; \text { Senegal, } n=5 ; \\
\text { Guinea, } n=2 ; \text { Togo, } \\
n=2 ; \text { Niger, } n=1 ; \\
\text { Mauritania, } n=1 ; \text { West } \\
\text { Indies, } n=4\end{array}$ & $\begin{array}{l}30-60 \text { days } \\
\quad(\text { median } 42)\end{array}$ & $\begin{array}{l}\text { Fever } 17.6 \% \text {, gastrointestinal } \\
\text { disorders } 17.6 \% \text {, VOC } 5 \%\end{array}$ \\
\hline $\begin{array}{l}\text { The risk of traveling abroad in } \\
\text { sickle cell disease }{ }^{2}\end{array}$ & 148 & $\begin{array}{l}\text { 18-56 years } \\
\quad \text { (median } \\
26.8)\end{array}$ & $\begin{array}{l}\text { Africa, } 49 \% \text {; Europe, } \\
\text { 27\%; West Indies, } \\
22 \% ; \text { Asia, } 2 \%\end{array}$ & Not reported & $\begin{array}{l}\text { VOC } 68 \% \text {, fever } 19 \% \text {, diarrhea } \\
19 \%, \text { bronchopulmonary } \\
\text { symptoms } 11 \% \text {, headaches } 8 \% \text {, } \\
\text { vomiting } 6 \% \text {, cutaneous wound } \\
4 \%\end{array}$ \\
\hline $\begin{array}{l}\text { Sickle cell children traveling } \\
\text { abroad: the primary risk is } \\
\text { infection }^{17}\end{array}$ & 42 & $\begin{array}{l}0.2-17.7 \text { years } \\
\quad(\text { median } 7.6)\end{array}$ & $\begin{array}{l}\text { Africa, } 100 \% \text { (Mali, West } \\
\text { Africa, Madagascar, } \\
\text { Morocco) }\end{array}$ & $\begin{array}{l}0.5-3 \text { months } \\
\text { (median } \\
1.29 \text { months) }\end{array}$ & $\begin{array}{l}\text { Fever } 9.6 \% \text {, malaria } 4.8 \% \text {, } \\
\text { gastrointestinal infection } 4.8 \% \text {, } \\
\text { VOC } 2 \% \text {, urinary tract infection } \\
2 \%\end{array}$ \\
\hline $\begin{array}{l}\text { Acute splenic syndrome in an } \\
\text { African-American male with } \\
\text { sickle cell trait on a commercial } \\
\text { airplane flight }\end{array}$ & 1 & 43 years & $\begin{array}{l}\text { San Diego, CA to } \\
\text { Newark, NJ on } \\
\text { commercial airline }\end{array}$ & A few hours & $\begin{array}{l}\text { Splenic infarction and subsequent } \\
\text { splenectomy }\end{array}$ \\
\hline $\begin{array}{l}\text { Sudden death during } \\
\text { long-distance air travel in an } \\
\mathrm{HbS} / \mathrm{C} \text { disease patient }{ }^{58}\end{array}$ & 1 & 41 years & Kuala Lumpur, Malaysia & $\begin{array}{l}2 \text { hours prior } \\
\text { to landing }\end{array}$ & $\begin{array}{l}\text { Sudden death from pulmonary } \\
\text { thrombo-embolism }\end{array}$ \\
\hline $\begin{array}{l}\text { Airline travel in sickle cell } \\
\text { disease }\end{array}$ & 73 & 25 years & $\begin{array}{l}\text { Between Jamaica and } \\
\text { Miami }\end{array}$ & Not reported & VOC in 1 patient $(1.4 \%)$ \\
\hline $\begin{array}{l}\text { Risk of altitude exposure in sickle } \\
\text { cell disease }\end{array}$ & 45 & $10-62$ years & $\begin{array}{l}\text { Commercial airline trips: } \\
\text { Reno, NV and Lake } \\
\text { Tahoe, CA }\end{array}$ & $\begin{array}{l}\text { Air travel } \\
\text { time- } \\
\begin{array}{l}1-14 \text { hours; } \\
\text { mountain } \\
\text { exposure- } \\
\text { not reported }\end{array}\end{array}$ & $\begin{array}{l}\text { Mountain exposure-splenic crisis } \\
(15 \%) \text {, VOC }(42 \%) \text {; Air } \\
\text { travel-splenic crisis }(12.5 \%) \text {, } \\
\text { VOC }(10 \%)\end{array}$ \\
\hline
\end{tabular}


marrow transplantation is a rarely available but potentially curative option.

\section{Vaso-occlusive Pain Crisis}

One of the more common complications for travelers with SCD is vaso-occlusive pain crisis (VOC). A number of factors associated with travel, including dehydration, infection, altitude, and weather changes, are known to precipitate acute pain crisis. The literature review has demonstrated that of travelers with SCD hospitalized while abroad, $2 \%$ to $68 \%$ were hospitalized because of VOC. ${ }^{2,16,17}$ A French study noted that VOC was the most common medical event affecting adult travelers with SCD. It also noted that the patients who developed VOC during travel were not necessarily those who suffered symptomatic disease prior to travel. ${ }^{2}$ This emphasizes that even patients without frequent episodes of VOC should be made aware of the risk of this complication. Travelers should maintain adequate hydration and consider traveling with appropriate dosing of opioid analgesics.

\section{Bacterial Infections}

Individuals with SCD, particularly children, are at high risk for serious bloodstream infections. While VOC may be the most common complication in adult travelers with SCD, infection carries the highest risk among children. ${ }^{16}$ This is primarily due to functional asplenia, which develops early in childhood. Because of the increased risk of bacterial sepsis in patients with SCD, any fever (for children $>38.3^{\circ} \mathrm{C}$ once or persistently $>38.0$ and $>38.5^{\circ} \mathrm{C}$ for adults) must be urgently evaluated. Basic laboratory evaluation includes complete blood count (CBC), urinalysis, chest X-ray, and cultures of the blood and urine. Ill-appearing children and those with a temperature higher than $40^{\circ} \mathrm{C}$ should be admitted to the hospital. Nontoxic-appearing children with a temperature less than $40^{\circ} \mathrm{C}$, without infiltrate on chest $\mathrm{X}$-ray, without a history of sepsis, and with a reassuring complete blood count may be managed as outpatients if a close follow-up can be ensured. These children can be observed at home after parenteral administration of a long-acting antibiotic that covers S. pneumoniae (pneumococcus) and Haemophilus influenzae..$^{10}$ Pneumococcus is the most common and the most important cause of bacteremia in SCD. This risk is substantial: before current preventative strategies were developed, the incidence of invasive pneumococcal disease was as high as six episodes of bacteremia per 100 patient years, with a peak in the first 3 years of life. ${ }^{11}$

Because the risk of pneumococcal bacteremia is so great, the current standard of care is to initiate prophylactic penicillin therapy in children with SCD immediately on diagnosis. ${ }^{10,12}$ The benefit of prophylactic penicillin diminishes after 5 years of age, and most hematologists with expertise in SCD recommend cessation of prophylactic penicillin at this point. ${ }^{13,14}$ In select cases, such as a history of surgical splenectomy or a history of pneumococcal sepsis, antibiotics may be continued indefinitely. The role of prophylactic penicillin is controversial in patients with certain heterozygous SCD variants, such as type $\mathrm{SC}$ and $\mathrm{S} \beta^{+}$thalassemia. ${ }^{15}$

It is well established that patients with SCD are vulnerable to complicated Salmonella infections, particularly bacteremia and osteomyelitis. The current medical literature contains relatively few documented cases of Salmonella infections among travelers with SCD, so the absolute risk for a traveler is uncertain. In one series of 39 children with SCD who had traveled to Africa, two children developed Salmonella bacteremia. ${ }^{16}$ In one of the two cases, the child had multifocal osteomyelitis. In a separate study of 42 children with SCD, of four hospitalizations occurring after return home, one toddler suffered Salmonella typhimurium bacteremia complicated by osteomyelitis. ${ }^{17}$ On the other hand, among 148 adult travelers with SCD, none developed a Salmonella infection. $^{2}$

International travel brings the additional challenge of exposure to travel-associated pathogens. The risk for developing an infection is increased by younger age, longer duration of travel, or unsanitary living conditions. ${ }^{17}$ The epidemiology of bacteremia among indigenous Africans with SCD varies by region and appears to differ from what patients experience in North America. ${ }^{18}$ Staphyloccocus aureus and $H$. influenzae have been found to be important pathogens in studies from both West and East Africa. ${ }^{19,20}$ However, other studies have demonstrated the primary organisms causing bacteremia to be nontyphi Salmonella (NTS) and Klebsiella. ${ }^{21,22}$ A study focusing on East Africa found that $90 \%$ of isolates in bacteremia were due to five primary organisms, including S. pneumoniae, $H$. influenzae type B (HiB), NTS, Acinetobacter species, and Escherichia coli. ${ }^{23}$ It is not known whether these studies are generalizable to a traveler to Africa.

\section{Malaria}

The HbS gene and malaria share a fascinating coevolutionary history. The HbS polymorphism has arisen independently multiple times within Africa, the Arabian Peninsula, and the Indian subcontinent during our recent evolutionary history, as have other hemoglobin polymorphisms such as hemoglobin $\mathrm{C}$. The geographic concordance between $\mathrm{HbS}$ gene frequency and malaria transmission is more than coincidental. There is abundant evidence that individuals with sickle cell trait (ie, heterozygous for the HbS allele) suffer less frequent and less severe bouts of malaria. ${ }^{24,25}$ Together these data suggest that malaria has produced a profound selective pressure on the hemoglobin beta chain gene.

What is less clear is how the sickle cell homozygous state, that is, SCD itself, influences the risk of 
parasitemia and of severe malaria. Malaria appears to be common among African patients with $\mathrm{SCD},{ }^{26,27}$ but some studies suggest that parasitemia ${ }^{28-30}$ and severe malarial anemia ${ }^{31}$ are less common among them than they are among the general population. These studies are limited in a number of respects, including the fact that intensity of malaria transmission varies greatly with season and locale. The denominator of patients studied, that is, age group, rural versus urban, and hospitalized versus nonhospitalized patients makes it difficult to generalize from any one study. Finally, there are many confounders such as the improvement in standard of living and primary medical care in many regions of Africa; on the other hand, there is also the crisis of antimalarial drug resistance.

While the $\mathrm{HbS}$ allele may provide protection against malaria, this body of research should in no way diminish the importance of malaria prevention strategies for travelers to an endemic region. Even for healthy patients with the sickle cell trait, it must be remembered that studies have shown decreased severity of malaria in indigenous populations. Because of repeated exposure, these subjects likely had a degree of acquired immunity, which cannot be assumed in any traveler. Regardless of their risk compared with the general population, among SCD patients within Africa, ${ }^{3}$ malaria remains a major cause of morbidity and mortality, and the risk in a nonimmune traveler with SCD who does not recognize the symptoms of malaria will almost certainly be higher. Indeed, imported malaria has been documented among international travelers with SCD and trait; this includes a family in which two children with SCD and three with sickle trait developed Plasmodium falciparum malaria. ${ }^{32}$ Three of the family members developed a life-threatening infection.

All major prophylactic agents for malaria (mefloquine, atovaquone-proguanil, doxycycline, and chloroquine where it is appropriate) are acceptable, and should be urged for all patients with SCD, including young infants. In addition to chemoprophylaxis, the travel provider should urge patients with SCD to use appropriate insect repellents [eg, $N, N$-diethyl- $m$-toluamide (DEET), picaridin], insecticidal sprays for clothing (eg, permethrin), and insecticide-impregnated bed nets if they are sleeping in dwellings that are not climate-controlled with adequately screened windows and doors. Providing therapeutic antimalarials for presumptive self-treatment is advisable only in the rare case when an individual does not have immediate access to medical care while abroad. Not all malaria-like illnesses are malaria, and self-treatment for malaria should not mitigate the urgency of a medical evaluation. Rapid diagnostic kits for malaria are interpreted poorly when used for self-diagnosis by laypersons, and they cannot be recommended for a traveler with SCD.

As far as possible, vulnerable travelers should avoid likely mosquito habitats, such as marshy or wet areas, and limit activity after dusk when malaria is most likely to be transmitted. Finally, travel medicine providers should counsel patients with SCD about the symptoms of malaria and advise prompt medical evaluation for febrile illnesses during or after travel.

\section{Other Travel-Associated Infections}

There is a wide array of important infections that may affect travelers to developing countries. There is essentially no systematic literature about their relevance to patients with SCD. There have been a few reported cases of Shigella bacteremia in SCD patients. ${ }^{33}$ A study of 40 patients from Iraq found a higher prevalence of the protozoal intestinal pathogens Giardia lamblia and Cryptosporidium species among patients with SCD. ${ }^{34}$ Schistosoma mansoni infection does not appear to be more common or more severe among patients with hemoglobinopathies. ${ }^{35}$ A number of reports describe fatal dengue fever in patients with SCD. ${ }^{36-38}$ In aggregate, these case reports suggest an association between severe dengue and SCD; however, a dedicated case-control study has not been performed. A French study investigated the epidemiological and clinical pattern of tuberculosis in 12 adult patients with SCD. This study found that lymphatic tuberculosis was more common in SCD patients than in otherwise healthy patients with tuberculosis. Interestingly, the study also noted that pulmonary tuberculosis in SCD was less common than expected. ${ }^{39}$

\section{Vaccination}

\section{Routine Vaccinations}

Individuals with SCD receive all routine childhood immunizations according to the schedule for otherwise healthy children, including live-attenuated vaccinations such as the measles-mumps-rubella and varicella vaccines. In the United States, this vaccine schedule includes a four-dose series of the 13-valent protein conjugate pneumococcal vaccine (PCV13 or Prevnar 13). ${ }^{40}$ In contrast to normal children, however, children with SCD should also receive the 23 -valent pneumococcal polysaccharide vaccine (PPSV23 or Pneumovax). This vaccine is given to children over 24 months of age at least 8 weeks after they have completed their PCV13 series. A second dose of PPSV23 is recommended 5 years after the first dose for adults aged 19 to 64 years. No additional doses are needed until age 65 . Those who receive PPSV23 before age 65 should receive another dose of the vaccine at age 65 or later if at least 5 years have passed. $^{41}$

Many European countries, including Bulgaria, Germany, Greece, and the Netherlands, recommend a similar four-dose series of the pneumococcal vaccine. A three-dose pneumococcal vaccine recommendation is made by the UK, consisting of a primary course of two doses at 2 and 4 months of age, with a final third dose at 13 months. France, Belgium, and Austria have similar recommendations. ${ }^{41}$ Nineteen European countries 
have specific recommendations for the use of PPSV23 in patients with splenic dysfunction such as those with SCD. These countries include Austria, Belgium, the Czech Republic, Cyprus, Denmark, England, Estonia, Finland, France, Germany, Ireland, Latvia, Lithuania, Luxemburg, the Netherlands, Norway, Slovakia, Sweden, and Switzerland. ${ }^{42}$

The conjugate vaccine for $\mathrm{HiB}$ is also a part of the routine vaccine series for children in the United States. Children receive a primary series of 2 to 3 doses (depending on the formulation) during infancy, followed by a booster at 12 to 15 months. ${ }^{42}$ This series is typically sufficient for antibody production, so no further boosters are necessary for patients with SCD.

The World Health Organization (WHO) recommends conjugate $\mathrm{HiB}$ vaccines in all routine infant immunization programs. By 2009, 47 countries in the WHO European Region had introduced and were routinely implementing immunization with HiB-containing vaccines. ${ }^{44}$ Most European countries follow the US recommendations for a two- to three-dose series between the ages of 2 to 6 months, followed by a booster at 12 to 15 months. In Estonia, Hungary, Lithuania, Malta, Portugal, and Spain, the booster is given at 18 to 24 months. ${ }^{41}$

Current immunization recommendations in the United States also include the quadrivalent conjugate meningococcal vaccine (MCV4) for all individuals between 11 and 18 years of age. MCV4 elicits antibodies that are protective against Neisseria meningitides serogroups A, C, Y, and W-135. MCV4 is recommended between ages 2 and 10 for children at increased risk for invasive meningococcal disease. ${ }^{42}$ In 2012, a conjugate tetravalent vaccine that can be administered as a single dose from the age of 1 year was licensed in Europe. ${ }^{44}$ Adults with SCD who have not previously received a meningococcal vaccine should strongly consider immunization before travel to areas where epidemic meningococcal disease is prevalent. ${ }^{10}$ This pertains particularly to travel to the Sahel (the semi-desert region immediately south of the Sahara), the Arabian Peninsula, and the Indian subcontinent.

Patients with SCD are at high risk for complications of influenza; these complications include ACS, pain crisis, and invasive bacterial infection. Bundy and colleagues analyzed hospitalizations from four states in the United States (California, Florida, Maryland, and New York) across two influenza seasons (2003-2004 and 2004-2005) and found that children with SCD were hospitalized for influenza at 56 times the rate of children without SCD. ${ }^{43}$ This study emphasizes the importance of annual influenza vaccinations for individuals with SCD.

\section{Travel Vaccinations}

Individuals with SCD may receive all age- and destination-appropriate travel vaccinations. Hepatitis A vaccination is now standard for children under 2 years of age in the United States. This is not the case in most European countries. Hepatitis A vaccine is specifically recommended only in Greece and Austria. Cyprus and the Czech Republic recommend hepatitis A vaccine in specific at-risk groups. ${ }^{41}$ Live vaccines, such as yellow fever vaccination, may be administered to SCD patients before travel to endemic areas in Africa or the Americas. Both injectable and oral attenuated typhoid vaccinations are acceptable in SCD patients. There is no evidence that patients with SCD are at particular risk from the oral attenuated typhoid vaccine.

\section{Diarrheal Illness and Hypovolemia}

Diarrheal illness is a common affliction among travelers to developing countries. Patients with SCD are uniquely susceptible to developing hypovolemia and free water deficits because of chronic microvascular renal disease. ${ }^{44}$ One consequence of this is hyposthenuria, the inability to concentrate urine appropriately. ${ }^{45}$ This phenomenon has been observed as early as 6 to 12 months of age. Hypovolemia may be further exacerbated by various factors during travel to tropical regions, such as exposure to heat and sun, lack of access to safe drinking water, and diarrheal illnesses such as travelers' diarrhea. Because erythrocyte sickling is more likely to happen in the setting of a volume deficit, this confluence of risks can predispose travelers with SCD to a vaso-occlusive sickle cell crisis during travel.

Strategies to minimize exposure to enteric pathogens, specifically, avoiding potentially contaminated food and water, are crucial for individuals with SCD. There are a variety of strategies for the treatment of drinking water, and for making safe food choices while traveling in developing countries. ${ }^{46}$ Oral electrolyte replacement solution (ORS) is widely available both in the United States and abroad, and it would be wise for patients with SCD to procure ORS prior to travel. Patients with SCD may need a lower threshold to seek medical attention for gastroenteritis, especially when it is accompanied by signs of hypovolemia, inability to tolerate oral fluids, or complications such as fever or signs of dysentery. ${ }^{46}$ Presumptive antibiotic treatment of travelers' diarrhea has become the standard of care for healthy travelers; it is certainly advisable in travelers with SCD. Fluoroquinolones are often used for empiric treatment of travelers' diarrhea in adults. Azithromycin can be used for this indication in children. ${ }^{47,48}$

\section{Air Travel and Altitude}

Flying in pressurized aircraft usually poses no problems for sickle cell patients. The most important considerations are to dress warmly, drink plenty of fluids, and to move about the cabin as often as possible. ${ }^{10}$ Erythrocyte sickling and, therefore, SCD complications can, however, be induced by mild hypoxemia. Mountain elevations or travel in planes that maintain cabin pressure at 
approximately 5,000 to $7,000 \mathrm{ft}(1,500-2,100 \mathrm{~m})$ is associated with a drop in arterial oxygen pressure $\left(\mathrm{PaO}_{2}\right)$ that may affect patients with SCD adversely. ${ }^{49}$ During air travel, VOC may occur in up to $8.7 \%$ of patients with $\mathrm{HbS}$. At mountain altitudes, patients with SCD may have as high as a $38 \%$ risk for developing VOC. ${ }^{52} \mathrm{Com}-$ plications such as splenic infarction have been noted at high altitudes (over 10,000 ft or 3,000 m) even in patients with sickle cell trait-a genotype that is generally asymptomatic. ${ }^{10,49}$

Prolonged air travel is a well-established risk factor for venous thromboembolism (VTE) ${ }^{50}$ SCD itself is a thrombophilic state - in one study, the prevalence of pulmonary embolism (PE) in hospitalized SCD patients younger than 40 years was approximately 3.5 times higher than in African-American controls. ${ }^{51}$ Current recommendations, however, rely only on individual assessment of risk factors for thrombosis and bleeding. ${ }^{52}$ Knee-high graduated compression stockings or a single dose of low-molecular-weight heparin are options to prevent travel-associated VTE in select cases. ${ }^{50}$

\section{Preparedness for Travel and Access to Care While Abroad}

Because of the unique travel needs and medical complications of patients with SCD, it is important for travelers with SCD to know where they can access medical care while abroad. An important resource is the Global Sickle Cell Disease Network (GSCDN), http://www.globalsicklecelldisease.org. This is a worldwide network of researchers and clinicians working in collaboration to help the global SCD community. Their website includes an SCD treatment center map to provide information about the location and the services provided by treatment centers all over the world. Prior to travel, families should know the closest center and make a note of the services available. It is also important that they have transportation and financial support available if emergency medical services are needed.

Blood transfusion services available in Africa may be difficult to access. The WHO has recommended that countries develop nationally coordinated blood services that are community-based. These services should rely on voluntary nonremunerated blood donors to donate blood. Despite the recommendation, less than $20 \%$ of sub-Saharan African countries have implemented this system. ${ }^{53}$ Transfusion practices in most African countries are hospital-based and rely on blood donations from patients' family members. Unfortunately, this system does not provide sufficient blood to meet the clinical needs of many patients. Testing for transfusion-transmissible diseases is also less uniform in the developing world. A sizeable proportion of human immunodeficiency virus (HIV) transmission in Africa has been attributed to blood transfusions. ${ }^{54}$ Blood is not routinely tested for malaria, microfilariae, and other blood-borne pathogens. ${ }^{55}$ For this reason, SCD patients on a chronic transfusion protocol (such as those with a history of stroke) may be encouraged to limit their length of stay to avoid possible transfusion-related complications.

All patients with SCD who are planning travel abroad should be evaluated by a trained specialist in travel medicine (Table 2). Such visits are most productive when scheduled well in advance of travel. Patients should also discuss their plans with their hematologist. All patients should plan to carry a letter from their hematologist explaining diagnosis, treatment plan (including prescription of narcotics and other medications), and complications of their disease. This may facilitate appropriate medical care overseas. Patients may also require permission to carry medications on board the aircraft. All medications should be appropriately and clearly labeled. This is particularly relevant for narcotic pain medications, which many patients with SCD require for managing pain crises. The US Transportation Security Administration (TSA) states that passengers with medical conditions are not subject to the same restrictions for their liquid medications as are imposed on other liquids. ${ }^{56}$ However, if the liquid exceeds the general allowance, it must be declared to the TSA agent and be separated from other liquids. Further medication policies vary by airline and specific area of travel. Other countries of origin may have different requirements. It is important for patients to consult their airline regarding these policies prior to travel. In addition, patients with SCD are urged to purchase

Table 2 Summary of recommendations for the travel medicine professional evaluating a traveler with sickle cell disease (SCD)

\footnotetext{
Maintenance of routine care

Ensure adequate supply of routine medications (eg, hydroxyurea penicillin, and pain medications).

Ensure traveler has identified where he/she can get emergency care.

For extended travel, ensure traveler makes the effort to identify a hematologist abroad.

Malaria prevention

Individuals with SCD should receive malaria prophylaxis when traveling to destinations where prophylaxis would otherwise be recommended.

All chemoprophylactic agents are acceptable in individuals with SCD.

Vaccinations

Ensure that prior to travel, travelers with SCD have received all age-appropriate vaccinations, and vaccinations uniquely recommended for SCD (pneumococcal polysaccharide vaccine, influenza vaccine).

All travel vaccinations, including live-attenuated vaccines, are acceptable.

Diarrheal illness and hypovolemia

Instruct regarding preparation of clean drinking water. Provide antimicrobials for treatment of travelers' diarrhea. Encourage purchase and use of oral rehydration solution

Travel preparedness

Encourage taking out insurance policies covering trip cancelation and medical evacuation.
} 
insurance policies covering trip cancelation and medical evacuation / repatriation in the event of a medical emergency overseas.

The rewards of international travel can be substantial for patients with SCD who have experienced a lifetime of chronic illness. International travel may be associated with higher risks and require detailed preparation. However, with advanced planning and involvement of their medical care providers, patients and their families can manage their travel safely and in a well-informed manner.

\section{Acknowledgments}

Dr Lantos was supported by the National Center for Advancing Translational Sciences of the National Institutes of Health under Award Number KL2TR001115. The content is solely the responsibility of the authors and does not necessarily represent the official views of the National Institutes of Health.

\section{Declaration of Interests}

The authors state they have no conflicts of interest to declare.

\section{References}

1. Platt OS, Brambilla DJ, Rosse WF, et al. Mortality in sickle cell disease. Life expectancy and risk factors for early death. N Engl J Med 1994; 330:1639-1644.

2. Stankovic Stojanovic K, Lionnet F, Girot R, et al. The risk of going abroad in sickle cell disease: a study of 148 adults. Trans R Soc Trop Med Hyg 2011; 105:310-314.

3. Makani J, Williams TN, Marsh K. Sickle cell disease in Africa: burden and research priorities. Ann Trop Med Parasitol 2007; 101:3-14.

4. Aygun B, Odame I. A global perspective on sickle cell disease. Pediatr Blood Cancer 2012; 59:386-390.

5. Weatherall D, Akinyanju O, Fuchareon S. Inherited disorders of hemoglobin. In: Jamison DT, ed. Disease control priorities in developing countries. 2nd Ed. Washington: Oxford University Press, World Bank, 2006.

6. Brandow AM, Panepinto JA. Monitoring toxicity, impact, and adherence of hydroxyurea in children with sickle cell disease. Am J Hematol 2011; 86:804-806.

7. Kinney TR, Helms RW, O'Branski EE, et al. Safety of hydroxyurea in children with sickle cell anemia: results of the HUG-KIDS study, a phase I/II trial. Pediatric Hydroxyurea Group. Blood 1999; 94:1550-1554.

8. Nzouakou R, Bachir D, Lavaud A, et al. Clinical follow-up of hydroxyurea-treated adults with sickle cell disease. Acta Haematol 2011; 125:145-152.

9. Wang WC, Ware RE, Miller ST, et al. Hydroxycarbamide in very young children with sickle-cell anaemia: a multicentre, randomised, controlled trial (BABY HUG). Lancet 2011; 377:1663-1672.

10. National Heart Lung and Blood Institute. Division of Blood Diseases and Resources. The management of sickle cell disease. 4th Ed. Bethesda: National Heart Lung and Blood Institute, 2002.
11. Whitney CG, Farley MM, Hadler J, et al. Decline in invasive pneumococcal disease after the introduction of protein-polysaccharide conjugate vaccine. N Engl J Med 2003; 348:1737-1746.

12. Gaston MH, Verter JI, Woods G, et al. Prophylaxis with oral penicillin in children with sickle cell anemia. A randomized trial. N Engl J Med 1986; 314:1593-1599.

13. Falletta JM, Woods GM, Verter JI, et al. Discontinuing penicillin prophylaxis in children with sickle cell anemia. Prophylactic Penicillin Study II. J Pediatr 1995; 127:685-690.

14. McCavit TL, Gilbert M, Buchanan GR. Prophylactic penicillin after 5 years of age in patients with sickle cell disease: a survey of sickle cell disease experts. Pediatr Blood Cancer 2013; 60:935-939.

15. McCavit TL. Sickle cell disease. Pediatr Rev 2012; 33:195-204.

16. Sommet J, Missud F, Holvoet L, et al. Morbidity among child travellers with sickle-cell disease visiting tropical areas: an observational study in a French tertiary care centre. Arch Dis Child 2013; 98:533-536.

17. Runel-Belliard C, Lesprit E, Quinet B, Grimprel E. Sickle cell children traveling abroad: primary risk is infection. $\mathrm{J}$ Travel Med 2009; 16:253-257.

18. Battersby AJ, Knox-Macaulay HH, Carrol ED. Susceptibility to invasive bacterial infections in children with sickle cell disease. Pediatr Blood Cancer 2010; 55:401-406.

19. Akuse RM. Variation in the pattern of bacterial infection in patients with sickle cell disease requiring admission. J Trop Pediatr 1996; 42:318-323.

20. Kizito ME, Mworozi E, Ndugwa C, Serjeant GR. Bacteraemia in homozygous sickle cell disease in Africa: is pneumococcal prophylaxis justified? Arch Dis Child 2007; 92:21-23.

21. Aken'ova YA, Bakare RA, Okunade MA. Septicaemia in sickle cell anaemia patients: the Ibadan experience. Cent Afr J Med 1998; 44:102-104.

22. Akinyanju O, Johnson AO. Acute illness in Nigerian children with sickle cell anaemia. Ann Trop Paediatr 1987; $7: 181-186$

23. Williams TN, Uyoga S, Macharia A, et al. Bacteraemia in Kenyan children with sickle-cell anaemia: a retrospective cohort and case-control study. Lancet 2009; 374:1364-1370.

24. Allison AC. Protection afforded by sickle-cell trait against subtertian malareal infection. Br Med J 1954; 1:290-294.

25. Williams TN, Mwangi TW, Wambua S, et al. Sickle cell trait and the risk of Plasmodium falciparum malaria and other childhood diseases. J Infect Dis 2005; 192:178-186.

26. Ambe JP, Fatunde JO, Sodeinde OO. Associated morbidities in children with sickle-cell anaemia presenting with severe anaemia in a malarious area. Trop Doct 2001; $31: 26-27$.

27. Ibidapo MO, Akinyanju OO. Acute sickle cell syndromes in Nigerian adults. Clin Lab Haematol 2000; 22:151-155.

28. Aluoch JR. Higher resistance to Plasmodium falciparum infection in patients with homozygous sickle cell disease in western Kenya. Trop Med Int Health 1997; 2:568-571.

29. Awotua-Efebo O, Alikor EA, Nkanginieme KE. Malaria parasite density and splenic status by ultrasonography in stable sickle-cell anaemia (HbSS) children. Niger J Med 2004; 13:40-43.

30. Okuonghae HO, Nwankwo MU, Offor E. Malarial parasitaemia in febrile children with sickle cell anaemia. J Trop Pediatr 1992; 38:83-85. 
31. Aidoo M, Terlouw DJ, Kolczak MS, et al. Protective effects of the sickle cell gene against malaria morbidity and mortality. Lancet 2002; 359:1311-1312.

32. Glikman D, Nguyen-Dinh P, Roberts JM, et al. Clinical malaria and sickle cell disease among multiple family members in Chicago, Illinois. Pediatrics 2007; 120:e745-e748.

33. Evans HE, Sampath AC, Douglass F, Baki A. Shigella bacteremia in a patient with sickle cell anemia. Am J Dis Child 1972; 123:238-239.

34. Mahdi NK, Ali NH. Intestinal parasites, including Cryptosporidium species, in Iraqi patients with sickle-cell anaemia. East Mediterr Health J 2002; 8(2-3):345-349.

35. Cook JA, Kellermeyer WF Jr, Warren KS, Kellermeyer RW. Sickle cell haemoglobinopathy and Schistosoma mansoni infection. Ann Trop Med Parasitol 1972; 66:197-202.

36. Moesker FM, Muskiet FD, Koeijers JJ, et al. Fatal dengue in patients with sickle cell disease or sickle cell anemia in Curacao: two case reports. PLoS Negl Trop Dis 2013; 7:e2203.

37. Limonta D, Gonzalez D, Capo V, et al. Fatal severe dengue and cell death in sickle cell disease during the 2001-2002 Havana dengue epidemic. Int J Infect Dis 2009; 13:e77-e78.

38. Bravo JR, Guzman MG, Kouri GP. Why dengue haemorrhagic fever in Cuba? 1. Individual risk factors for dengue haemorrhagic fever/dengue shock syndrome (DHF/DSS). Trans R Soc Trop Med Hyg 1987; 81:816-820.

39. Lionnet F, Bachmeyer C, Sloma I, et al. Tuberculosis in adult patients with sickle cell disease. J Infect 2007; 55:439-444.

40. Nuorti JP, Whitney CG, Centers for Disease Control and Prevention. Prevention of pneumococcal disease among infants and children-use of 13-valent pneumococcal conjugate vaccine and 23 -valent pneumococcal polysaccharide vaccine-recommendations of the Advisory Committee on Immunization Practices (ACIP). MMWR Recomm Rep 2010; 59(RR-11):1-18.

41. Group AAIW, Bridges CB, Woods L, Coyne-Beasley T, Centers for Disease Control and Prevention. Advisory Committee on Immunization Practices (ACIP) recommended immunization schedule for adults aged 19 years and older-United States, 2013. MMWR Surveill Summ 2013; 62(Suppl 1):9-19.

42. Group ACAIW, Akinsanya-Beysolow I, Jenkins R, Meissner HC, Centers for Disease Control and Prevention. Advisory Committee on Immunization Practices (ACIP) recommended immunization schedule for persons aged 0 through 18 years-United States, 2013. MMWR Surveill Summ 2013; 62(Suppl 1):2-8.

43. Bundy DG, Strouse JJ, Casella JF, Miller MR. Burden of influenza-related hospitalizations among children with sickle cell disease. Pediatrics 2010; 125:234-243.
44. Scheinman JI. Sickle cell disease and the kidney. Nat Clin Pract Nephrol 2009; 5:78-88.

45. da Silva GB Jr,, Liborio AB, Daher Ede F. New insights on pathophysiology, clinical manifestations, diagnosis, and treatment of sickle cell nephropathy. Ann Hematol 2011; 90:1371-1379.

46. Centers for Disease Control and Prevention. CDC health information for international travel. New York: Oxford University Press, 2012: 470-472.

47. Gomi H, Jiang ZD, Adachi JA, et al. In vitro antimicrobial susceptibility testing of bacterial enteropathogens causing traveler's diarrhea in four geographic regions. Antimicrob Agents Chemother 2001; 45:212-216.

48. Adachi JA, Ostrosky-Zeichner L, DuPont HL, Ericsson CD. Empirical antimicrobial therapy for traveler's diarrhea. Clin Infect Dis 2000; 31:1079-1083.

49. Claster S, Godwin MJ, Embury SH. Risk of altitude exposure in sickle cell disease. West J Med 1981; 135:364-367.

50. Philbrick JT, Shumate R, Siadaty MS, Becker DM. Air travel and venous thromboembolism: a systematic review. J Gen Intern Med 2007; 22:107-114.

51. Stein PD, Beemath A, Meyers FA, et al. Deep venous thrombosis and pulmonary embolism in hospitalized patients with sickle cell disease. Am J Med 2006; 119:897 e7-897 e11.

52. Naik RP, Streiff MB, Lanzkron S. Sickle cell disease and venous thromboembolism: what the anticoagulation expert needs to know. J Thromb Thrombolysis 2013; $35: 352-358$.

53. Field SP, Allain JP. Transfusion in sub-Saharan Africa: does a Western model fit? J Clin Pathol 2007; 60:1073-1075.

54. Hansasuta P, Rowland-Jones SL. HIV-1 transmission and acute HIV-1 infection. Br Med Bull 2001; 58:109-127.

55. Lara AM, Kandulu J, Chisuwo L, et al. Laboratory costs of a hospital-based blood transfusion service in Malawi. J Clin Pathol 2007; 60:1117-1120.

56. Transportation Security Administration. Medically necessary liquids: travelers with disabilities and medical conditions. Available at: http://www.tsa.gov/travelerinformation/medically-necessary-liquids. (Accessed 2013 Nov 23).

57. Murano T, Fox AD, Anjaria D. Acute splenic syndrome in an African-American male with sickle cell trait on a commercial airplane flight. J Emerg Med 2013; 45:e161-e165.

58. Nadesan K, Nagaratnam M. Sudden death during long distance air travel in an $\mathrm{Hb} \mathrm{S} / \mathrm{C}$ disease patient. J Clin Forensic Med 2001; 8:151-155.

59. Ware M, Tyghter D, Staniforth S, Serjeant G. Airline travel in sickle cell disease. Lancet 2008; 352:652. 